\title{
Flypaper Effect Pada Pendapatan Asli Daerah (PAD) Dan Dana Alokasi Umum (DAU) Terhadap Belanja Daerah (Studi Pada Pemerintahan Kabupaten/Kota di Provinsi Jawa Timur, Jawa Tengah dan Jawa Barat Periode 2011-2013)
}

\author{
Ade Irma Suryani \\ Fakultas Ekonomi dan Bisnis Islam, Universitas Islam Negeri Sunan Ampel Surabaya
}

E-mail: ade.irma.suryani1091@gmail.com

\begin{abstract}
This study aims to determine the effect of local revenue (PAD) and the General Allocation Fund (DAU) to the Expenditures of Regional as well as the possibility of flypaper effect on the country/city in East Java, Central Java and West Java the period 2011-2013. The method used in thus research is quantitative method. The population used is the district/city in East Java, Central and West Java. Sampling using purposive sampling and sample in this research is 100 district/cities with details of East Java Province 38 District/city, West Java 35 district/city and West Java 27 district/city.The data used in this research is secondary data which the data obtained from reports of Regional Budget obtained via the website Ministry of Finance of the Republic of Indonesia Directorate General of Regional Financial Balance. The analysis in this research is using descriptive analysis, classical assumption test and multiple linear regression. Result from this research that indicates that the local revenue (PAD) affects regional expenditure as well as with the General Allocation Fund (DAU) also affects regional expenditure and occurred flypaper effect on the country/city in East Java,Central Java and West Java periods 2011-2013.
\end{abstract}

Keywords : PAD, DAU, Flypaper Effect

\begin{abstract}
Abstrak
Penelitian ini bertujuan untuk mengetahui pengaruh Pendapatan Asli Daerah (PAD) dan Dana Alokasi Umum (DAU) terhadap Belanja Derah serta kemungkinan terjadinya Flypaper Effect pada pemerintahan kabupaten/kota di Provinsi Jawa Timur, Jawa Tengah dan Jawa Barat periode tahun 2011-2013. Metode yang digunakan dalam penelitian ini adalah metode kuantitatif. Populasi yang digunakan adalah kabupaten/kota di Provinsi Jawa Timur, Jawa Tengah dan Jawa Barat. Pengambilan sampel menggunakan purpose sampling dan sampel pada penelitian ini yaitu sebayak 100 kabupaten/kota dengan rincian Provinsi Jawa Timur 38 Kabupaten/Kota, Jawa Barat 35 Kabupaten/Kota dan Jawa Barat 27 Kabupaten/Kota. Data yang digunakan dalam penelitian ini yaitu data sekunder yang mana data diperoleh dari laporan Anggaran Pendapatan dan Belanja Daerah yang diperoleh melalui situs Departemen Keuangan Republik Indonesia Direktorat Jenderal Perimbangan Keuangan Daerah. Analisis pada penelitian ini yaitu menggunakan analisis deskriptif, uji asumsi klasik dan regresi linier berganda. Hasil dari penelitian ini yaitu menunjukkan bahwa Pendapatan Asli Daerah (PAD) berpengaruh terhadap Belanja Daerah begitupun dengan Dana Alokasi Umum (DAU) juga berpengaruh terhadap Belanja Daerah serta terjadi Flypaper Effect pada pemerintahan kabupaten/kota di Provinsi Jawa Timur, Jawa Tengah dan Jawa Barat periode 2011-2013.
\end{abstract}

Kata Kunci : PAD, DAU, Flypaper Effect

\section{Pendahuluan}

Sistem pemerintahan terpusat atau bisa juga disebut dengan sentralisasi mengalami banyak kekurangan dalam kegiatan operasionalnya, diantaranya yaitu: pekerjaan pemerintah pusat jadi banyak sehingga menghambat proses pelaksanaan di daerah, peraturan dari pusat sering tidak sesuai dengan keadaan suatu daerah dan 
rakyat di daerah tidak mendapatkan kesempatan untuk memikirkan inovasi apa yang diberikan kepada daerahnya agar daerah tersebut dapat berkembang.

Setelah terangkatnya Soeharto menjadi presiden yang kedua, maka munculah pemerintahan orde baru yang mengalami perubahan dalam tatanan pemerintah termasuk masalah pemerintahan yang terpusat. Pemeritahan pusat mulai memberikan kewenangan terhadap pemerintahan daerah untuk mengatur, mengurus sendiri urusan pemerintahannya, memilih pemimpin daerah sendiri, mengelola aparatur daerah, mengelola kekayaan daerah, memungut pajak daerah sendiri dan mengelola sumber daya yang ada di daerah tersebut.

Dengan kewenangan tersebut, maka pemerintahan daerah menetapkan sistem pemerintahan desentralisasi. Sistem desentralisasi membawa perubahan dalam penataan dan pengelolaan pemerintahan di daerah dengan adanya otonomi daerah. Kebijakan desentralisasi diterapkan di Indonesia melalui UU No. 22 tahun 1999 yang kemudian diganti menjadi UU No. 32 tahun 2004 yang menyatakan bahwaPemerintahan Daerah menjalankan otonomi yang luas, nyata dan bertanggung jawab untuk mempercepat terwujudnya kesejahteraan masyarakat melalui peningkatan pelayanan, pemberdayaan dan peran serta masyarakat. Di samping itu juga diarahkan untuk meningkatkan daya saing daerah berdasarkan potensi yang dimiliki.

Penyelenggaraan desentralisasi ini tentu saja memerlukan sumber pendanaan yang besar. Penyelenggaraan fungsi pemerintahan daerah akan terlaksana secara optimal apabila penyelenggaraan urusan pemerintahan diikuti dengan pemberian sumber-sumber penerimaan yang cukup kepada daerah. Sumber pendapatan daerah dalam rangka pelaksanaan desentralisasi terdiri dari Pendapatan Asli Daerah, Dana Perimbangan dan lain-lain pendapatan. Dalam UU No. 25 tahun 1999 yang direvisi menjadi UU No. 33 tahun 2004 yang menyatakan bahwa Pendapatan asli daerah terdiri dari pajak daerah, retribusi daerah, hasil pengolahan kekayaan daerah yang dipisahkan dan lain-lain pendapatan asli daerah yang sah. Dana perimbangan merupakan pendanaan daerah yang bersumber dari Anggaran Pendapatan dan Belanja Negara (APBD) yang terdiri dari Dana Bagi Hasil (DBH), Dana Alokasi Umum (DAU) dan Dana Alokasi Khusus (DAK). Dana Bagi Hasil (DBH) dan Dana Alokasi Umum (DAU) digolongkan ke dalam bentuk unconditional grants atau biasa disebut dengan dana/bantuan yang tak bersyarat, sedangkan Dana Alokasi Khusus (DAK) digolongkan ke dalam bentuk conditional grants atau biasa disebut dengan dana/bantuan bersyarat. Dimaksud sebagai dana bersyarat karena dana ini khusus hanya untuk suatu daerah, dan saat ini transfer tersebut khusus daerah Papua, Papua Barat dan Nanggroe Aceh Darussalam.

Menurut (Maimunah, 2006) Pada prakteknya, transfer dari pemerintah pusat merupakan sumber dana utama pemerintahan daerah untuk membiayai operasi utama sehari-hari, yang oleh pemerintah daerah dilaporkan dan diperhitungkan 
dalam APBD. Tujuan transfer adalah mengurangi (kalau tidak mungkin menghilangkan) kesenjangan fiskal antar pemerintahan dan menjamin tercapainya standart pelayanan publik minimum di seluruh negeri.

Penelitian sebelumnya telah banyak yang mengangkat permasalahan transfer ini, di Amerika Serikat, presentase transfer dari seluruh pendapatan mencapai 50\% untuk pemerintahan federal dan 60\% untuk pemerintahan daerah Fischer (dalam Maimunah, 2006). Khususnya di daerah Winconsin di AS sebesar 47\% pendapatan Pemerintahan Daerah berasal dari transfer Pempus Deller dkk (dalam Maimunah, 2006). Di Negara-negara lain, presentase transfer pengeluaran Pemda adalah $85 \%$ di Afrika Selatan, 67\%-95\% di Negeria, dan 70\%-90\% di Meksiko. Di Indonesia, pada masa sekarang ini, sesuai dengan UU No. 33 tahun 2004, transfer yang dalam hal ini disamakan istilahnya dengan Dana Alokasi Umum (DAU) ditetapkan sekurangkurangnya 26\% dari pendapatan dalam negeri netto yang ditetapkan dalam APBN.

Dalam penelitian ini terdapat suatu fenomena yang mana suatu kondisi ketika Pemerintahan Daerah merespon belanja daerahnya lebih banyak berasal dari transfer/grants daripada pendapatan asli dari daerahnya tersebut sehingga akan mengakibatkan pemborosan dalam Belanja Daerah yang disebut dengan Flypaper Effect.

Beberapa penelitian sebelumnya mengenai pengaruhnya PAD dan DAU terhadap Belanja Daerah (BD) memberikan hasil telah terjadinya flypaper effect pada beberapa daerah di Indonesia. Diantaranya penelitian yang dilakukan oleh (Hidayani, 2014) pada Provinsi Jawa Timur bahwa Pendapatan Asli Daerah dan Dana Alokasi Umum memiliki pengaruh terhadap Belanja Daerah sedangkan fenomena flypaper effect pada Provinsi Jawa Timur tidak ditemukan. Hal ini dikarenakan, Provinsi Jawa Timur mampu memenuhi salah satu faktor yang mempengaruhi keberhasilan penyelenggaraan otoda yaitu mampu meningkatkan partisipasi masyarakat dalam meningkatkan pendapatan asli daerahnya. Sedangkan pada penelitian Purbarini dan Masdjojo (2015) menyatakan bahwa Flypaper Effect terjadi pada belanja operasi pemerintahan kota di Indonesia. Dana Alokasi Umum dan Pendapatan Asli Daerah masing-masing berpengaruh positif dan signifikan terhadap Belanja Operasi. Berdasarkan uraian latar belakang diatas, penulis mengajukan penelitian dengan judul "Flypaper Effect Pada Pendapatan Asli Daerah (PAD) dan Dana Alokasi Umum (DAU) Terhadap Belanja Daerah (Studi Pada Pemeritahan Kabupaten/Kota di Provinsi Jawa Timur, Jawa Tengah dan Jawa Barat Periode 2011-2013)".

Berdasarkan pada uraian latar belakang, maka perumusan masalah dalam penelitian ini adalah : (1) Apakah Dana Alokasi Umum (DAU) berpengaruh terhadap Belanja Daerah (BD) Kabupaten/Kota di Provinsi Jawa Timur, Jawa Tengah \& Jawa Barat Periode 2011-2013? (2) Apakah Pendapatan Asli Daerah (PAD) berpengaruh terhadap 
(BD) Kabupaten/Kota di provinsi Jawa Timur, Jawa Tengah \& Jawa Barat Periode 2011-2013?(3) Apakah terjadi flypaper effect pada pengaruh DAU dan PAD terhadap Belanja Daerah (BD) Kabupaten/Kota di Provinsi Jawa Timur, Jawa Tengah \& Jawa Barat Periode 2011-2013?

\section{Metode}

\section{Rerangka Konseptual}

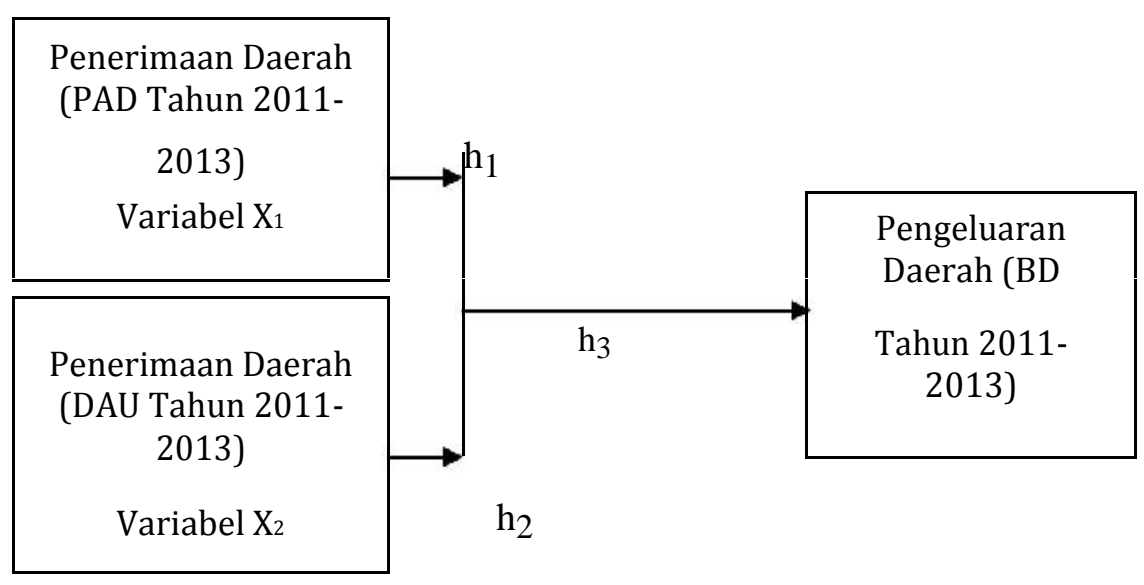

Berdasarkan asumsi diatas, maka hipotesis dalam penelitian ini adalah sebagai berikut:

h1: Terdapat pengaruh positif DAU terhadap BD

h2: Terdapat pengaruh positif PAD terhadap BD

h3 : Kemungkinan Terjadinya Flypaper Effect pada DAU dan PAD terhadap DAU

\section{Pendekatan Penelitian}

Penelitian ini dilakukan dengan metode kuantitatif, yang mana menurut Sugiyono(2012) Metode Kuantitatif disebut sebagai metode positivistik karena berlandaskan pada filsafat positivism. Metode ini sebagai metode ilmiah/scientific karena telah memenuhi kaidah-kaidah ilmiah yaitu, konkrit/empiris, obyektif, terukur, rasional dan sistematis. Metode ini juga disebut dengan metode discovery, karena dengan metode inidapat ditemukan dan dikembangkan berbagai iptek baru. Metode ini disebut metode kuantitatif karena data penelitian berupa angka-angka dan analisis menggunakan statistik. 


\section{Definisi Operasional, Identifikasi Variabel dan Indikator Variabel}

Menurut Sugiyono (2013) Variabel Penelitian adalah segala sesuatu yang berbentuk apa saja yang ditetapkan oleh peneliti untuk dipelajari sehingga diperoleh informasi tentang hal tersebut, kemudian ditarik kesimpulan.

\section{Variabel Independen (Variabel Bebas)}

Menurut Sugiyono (2013) mendefinisikan variabel bebas adalah merupakan variabel yang mempengaruhi atau yang menjadi sebab perubahannya atau timbulnya variabel dependen (terikat). Variabel dalam penelitian ini yaitu Pendapatan Asli Daerah ( $\left.\mathrm{X}_{1}\right)$ dan Dana Alokasi Umum (X2), maka indikator yang digunakan untuk menghitung dua variabel bebas tersebut masing-masing dirumuskan sebagai berikut:

\section{a) Pendapatan Asli Daerah ( $\left.X_{1}\right)$}

Pendapatan Asli Daerah (PAD) menurut Undang-Undang No. 33 Tahun 2004

Tentang Perimbangan Keuangan antara Pemerintahan Pusat dan PemerintahanDaerah"Pendapatan Asli Daerah, selanjutnya disebut PAD adalah Pendapatan yang diperoleh daerah yang dipungut berdasarkan Peraturan Daerah sesuai dengan peraturan perundang-undangan. Indikator yang digunakan yaitu dana dari penerimaan daerah. Dana dari penerimaan daerah yaitu:

1) Pajak Daerah

2) Retribusi Daerah

3) Hasil Pengelolaan Daerah yang dipisahkan, dan

4) Lain-lain Pendapatan Asli Daerah yang sah

\section{b) Dana Alokasi Umum ( $\left.\mathrm{X}_{2}\right)$}

Dana Alokasi Umum (DAU) menurut Undang-Undang No. 33 Tahun 2004 Tentang perimbangan Keuangan antara Pemerintahan Pusat dan Pemerintahan Daerah "Dana Alokasi Umum, selanjutnya disebut DAU adalah dana yang bersumber dari pendapatan APBN yang dialokasikan dengan tujuan pemerataan kemampuan keuangan antar daerah untuk mendanai kebutuhan daerah dalam rangka pelaksanaan desentralisasi". Indikator yang digunakan yaitu dana yang

1) Kabupaten/Kota Provinsi Jawa Timur, Jawa Tengah dan Jawa Barat yang mempublikasikan laporan Anggaran Pendapatan dan Belanja Daerah (APBD) tahun 2011-2013 kepada Dirjen Perimbangan Keuangan Pemerintahan Daerah. 
2) Kabupaten/Kota Provinsi Jawa Timur, Jawa Tengah dan Jawa Barat yang mencantumkan data mengenai PAD, DAU dan BD pada laporan realisasi APBD secara lengkap pada tahun 2011-2013.

\section{Jenis dan Sumber Data}

Pada penelitian ini, peneliti menggunakan jenis data yaitu kuantitatif. Sumber data yaitu diperoleh dari laporan Anggaran Pendapatan dan Belanja Daerah Pemerintahan Daerah Kabupaten/Kota di Provinsi Jawa Timur, Jawa Tengah dan Jawa Barat periode tahun 2011-2013 yaitu data PAD dan DAU serta total Belanja Daerah yang diperoleh dari situs Departemen Keuangan Republik Indonesia Direktorat Jenderal Perimbanggan Keuangan Daerah (www.djpkpd.go.id)

\section{Teknik Pengumpulan Data}

Teknik Pengumpulan data yang dilakukan peneliti dalam penelitian ini adalah sebagai berikut :

1) Penelitian Kepustakaan (Library Research)

Pada tahap ini, peneliti memperoleh data serta informasi-informasi untuk dijadikan sebagai landasan teori dan acuan untuk mengolah data dengan cara membaca, mempelajari, menelaah dan mengkaji literature-literatur berupa buku, jurnal, maupun penelitian-penelitian terdahulu yang berkaitan dengan masalah yang sedang diteliti.

2) Riset Internet (Online Research)

Pengumpulan data berasal dari situs-situs terkait untuk memperoleh tambahan literature, jurnal dan data yang yang berhubungan dengan penelitian ini.

\section{Teknik Analisis}

\section{1) Analisis Deskriptif}

Menurut Sugiyono (2012), Analisis Deskriptif adalah Statistik yang digunakan untuk menganalisa data dengan cara mendeskripsikan atau menggambarkan data yang telah terkumpul sebagaimana adanya tanpa bermaksud membuat kesimpulan yang berlakuuntuk umum atau generalisasi. Pengolahan data dalam penelitian ini menggunakan SPSS. 


\section{2) Uji Asumsi Klasik}

Untuk mendeteksi adanya penyimpangan asumsi klasik maka dilakukan uji normalitas, uji multikolonieritas, uji autokorelasi, dan uji heteroskedastisitas (Ghozali, 2009)

\section{3) Analisis Regresi Linier Berganda}

Analisis liniear berganda ini digunakan untuk melihat sejauh mana pengaruh variabel bebas yaitu Pendapatan Asli Daerah (X1) dan Dana Alokasi Umum (X2) terhadap variabel terikat yaitu Belanja Daerah (Y). Rumus regresi linear berganda yaitu:

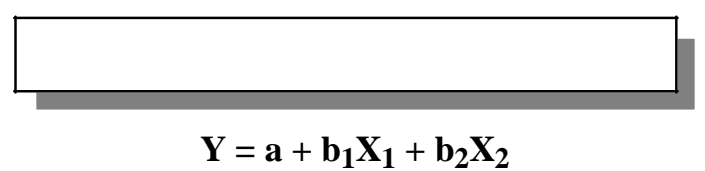

Dimana :

$\mathrm{Y}=$ Variabel terikat (Belanja Daerah)

$\mathrm{a}=$ Harga konstanta

$\mathrm{b}_{1}, \mathrm{~b}_{2}=$ Angka arah atau koefisien regresi masing-masing variabel $\mathrm{X}_{1}=$ Variabel bebas (Pendapatan Asli Daereah) $\mathrm{X}_{2}$

= Variabel bebas (Dana Alokasi Umum)

\section{Pengujian Hipotesis}

Pengujian hipotesis pada penelitian in yaitu uji regresi linier berganda, uji parsial (uji t), uji simultan (Uji F) dan uji koefisien determinan (R2).

\section{Hasil dan Pembahasan}

\section{Statistic Deskriptif}

\begin{tabular}{|c|c|c|c|c|}
\hline & & PAD & DAU & BD \\
\hline \multirow[t]{2}{*}{$\mathrm{N}$} & Valid & 56 & 56 & 56 \\
\hline & Missing & 0 & 0 & 0 \\
\hline \multicolumn{2}{|c|}{ Mean } & 562621.285 & 2217437.410 & 3977289.535 \\
\hline \multicolumn{2}{|c|}{ Std. Deviation } & 933707.646 & 771249.033 & 1898674.323 \\
\hline \multicolumn{2}{|c|}{ Minimum } & 128581 & 834836 & 1409703 \\
\hline \multicolumn{2}{|c|}{ Maximum } & 6957708 & 4451001 & 1.310385E7 \\
\hline
\end{tabular}

Sumber : Data diolah, 2016 


\section{Uji Asumsi Klasik}

\section{Uji normalitas}

\begin{tabular}{|ll|l|}
\hline $\mathrm{N}$ & & Unstandardized Residual \\
\hline Normal Parametersa & Mean & 56 \\
& Std. Deviation & .0000000 \\
Most Extreme Differences & Absolute & $.38373652 \mathrm{E} 5$ \\
& Positive & .104 \\
& Negative & -.075 \\
Kolmogorov-Smirnov Z & & .777 \\
Asymp. Sig. (2-tailed) & & .581 \\
\hline
\end{tabular}

Sumber: data diolah, 2016

Berdasarkan tabel diatas dapat di artikan bahwa nilai Signifikan pada one samplekolmogorove signorv test lebih dari 0.05 maka dapat dikatakan bahwa normalitasresidual dari persamaan regresi terdistribusi normal.

\section{Uji Multikolenearitas}

\begin{tabular}{|cc|c|c|c|}
\hline \multirow{2}{*}{} & & & \multicolumn{2}{c|}{ Collinearity Statistics } \\
\cline { 4 - 5 } & Model & Sig. & Tolerance & VIF \\
\hline 1 & (Constant) & .149 & & \\
& PAD & .000 & .929 & 1.076 \\
& DAU & .000 & .929 & 1.076 \\
\hline
\end{tabular}

Sumber: Data Diolah, 2016

Berdasarkan tabel 4.4 diatas menyatakan bahwa nilai Tolerance dan VIF di sekitar angka 10 sehingga dapat disimpulkan bahwa terjadi multikolinearitas.

\section{Uji Autokorelasi}

\begin{tabular}{|c|c|c|c|c|} 
Model & $\mathrm{R}$ & R Square & $\begin{array}{c}\text { Adjusted R } \\
\text { Square }\end{array}$ & $\begin{array}{c}\text { Durbin- } \\
\text { Watson }\end{array}$ \\
\hline 1 & $.992 \mathrm{a}$ & .984 & .984 & 2.275 \\
\hline
\end{tabular}

Sumber: Data Diolah, 2016

Berdasarkan hasil analisis diatas dapat ditunjukkan bahwa nilai Durbin Watson sebesar 2.275 dapat dikatakan normal apabila nilai DW berada diantara dU dan 4dU yang ditunjukkan dengan $2.2885<2.275<1.7115$ sehingga dapat diartikan bahwa tidak terjadi autokorelasi. 


\section{Uji Heteroskedasitas}

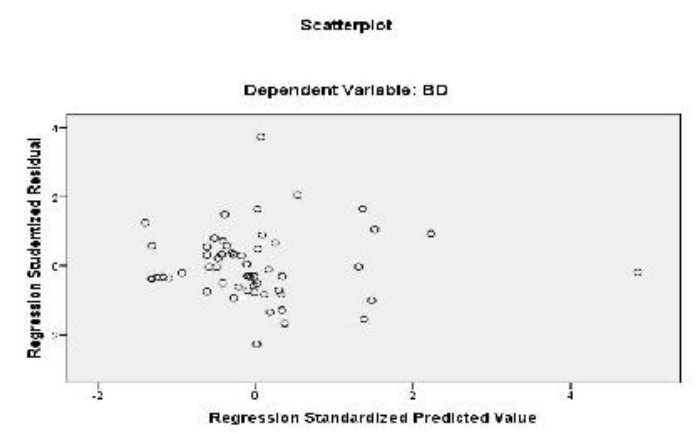

Gambar 4.1 diatas yang menyatakan bahwa grafik scatterplot dengan titik-titik yang menyebar secara acak tidak membentuk pola yang jelas maka dapat disimpulkan bahwa tidak terjadi heteroskedasitas pada model regresi

\section{Regresi Linier Berganda}

\begin{tabular}{|c|c|c|c|c|c|}
\hline & \multirow[b]{2}{*}{ Model } & \multicolumn{2}{|c|}{ Unstandardized Coefficients } & \multirow[b]{2}{*}{$\mathrm{t}$} & \multirow[b]{2}{*}{ Sig. } \\
\hline & & B & Std. Error & & \\
\hline \multirow[t]{3}{*}{1} & (Constant) & -146069.153 & 99726.816 & -1.465 & .149 \\
\hline & PAD & 1.265 & .036 & 34.780 & .000 \\
\hline & DAU & 1.539 & .044 & 34.937 & .000 \\
\hline
\end{tabular}

Sumber: Data Diolah, 2016

\section{Pengujian Hipotesis}

\section{Uji Parsial (Uji t)}

\begin{tabular}{|cc|c|c|c|c|}
\hline \multirow{2}{*}{\multicolumn{2}{|c|}{ Model }} & \multicolumn{2}{|c|}{ Unstandardized Coefficients } & & \\
\cline { 2 - 4 } & B & Std. Error & $\mathrm{t}$ & Sig. \\
\hline 1 & (Constant) & -146069.153 & 99726.816 & -1.465 & .149 \\
& PAD & 1.265 & .036 & 34.780 & .000 \\
& DAU & 1.539 & .044 & 34.937 & .000 \\
\hline
\end{tabular}

Sumber: Data Diolah, 2016

Berdasarkan tabel 4.7 diatas dapat dijelaskan uji hipotesis secara parsial atau individu sebagai berikut:

a. Tingkat signifikansi $0.000<0.05$ maka Ho ditolak Ha diterima, Sehingga dapat diartikan bahwa terdapat pengaruh yang signifikan variabel Pendapatan Asli Daerah (PAD) terhadap Belanja Daerah dengan ketentuan bahwa t-hitung $>t$ tabel $34.780>1.674$ 
b. Tingkat signifikansi $0.000<0.05$ maka Ho ditolak Ha diterima, Sehingga dapat diartikan bahwa terdapat pengaruh yang signifikan variabel Dana Alokasi Umum (DAU) terhadap Belanja Daerah dengan ketentuan bahwa t-hitung > t tabel 34.937 $>1.674$

\section{Uji Simultan (Uji F)}

\begin{tabular}{|c|c|c|c|} 
Model & $\mathrm{df}$ & $\mathrm{F}$ & Sig. \\
\hline Regression & 2 & $1.655 \mathrm{E} 3$ & $.000_{\mathrm{a}}$ \\
Residual & 53 & & \\
Total & 55 & & \\
\hline
\end{tabular}

Sumber : Data Diolah, 2016

Berdasarkan tabel 4.8 diatas dapat dijelaskan uji hipotesis secara simultan atau bersama-sama adalah tingkat signifikansi $0.000<0.05$, maka Ho ditolak $\mathrm{Ha}$ diterima, sehingga dapat diartikan bahwa terdapat pengaruh yang signifikan variabel Pendapatan Asli Daerah (PAD) dan Dana Alokasi Umum (DAU) terhadap Belanja Daerah (BD) dengan ketentuan bahwa thitung > t table 1.655E3 > 3.17

\section{Koefisien Determinan}

\begin{tabular}{|c|c|c|c|c|}
\hline Model & $\mathrm{R}$ & R Square & $\begin{array}{l}\text { Adjusted } \\
\text { R Square }\end{array}$ & $\begin{array}{c}\text { Durbin- } \\
\text { Watson }\end{array}$ \\
\hline 1 & $.992 \mathrm{a}$ & .984 & .984 & 2.275 \\
\hline
\end{tabular}

Sumber: Data Diolah, 2016

Berdasarkan hasil analisis yang di tunjukkan pada tabel 4.9 diatas dapat dijelaskan koefisien determinan pada penelitian ini sebesar 0.984 atau 98.4\%, sehingga variabel Pendapatan Asli Daerah (PAD) dewan dan Dana Alokasi Umum dapat menjelaskan Belanja Daerah dan siasanya 1.6\% dijelaskan oleh variabel lain.

\section{Analisis Flypaper Effect}

Berdasarkan hasil analisis pengujian hipotesis untuk menentukan apakah terjadi Flypaper Effect pada efek DAU terhadap BD dibandingkan dengan 
efek PAD terhadap BD. Syarat terjadi Flypaper Effect apabila efek (nilai koefisien) DAU terhadap BD lebih besar dari pada efek PAD terhadap BD dan keduanya samasama signifikan atau nilai DAU tidak signinifikan maka dapat disimpulkan terjadi Flypaper Effect. Berikut hasil regresi:

Tabel 4.10

Analisis Flypaper Effect

\begin{tabular}{|c|c|c|c|c|c|}
\hline \multirow{2}{*}{\multicolumn{2}{|c|}{ Model }} & \multicolumn{2}{|c|}{ Unstandardized Coefficients } & \multirow{2}{*}{$\begin{array}{l}\text { Standardized } \\
\text { Coefficients } \\
\text { Beta }\end{array}$} & \multirow[b]{2}{*}{ Sig. } \\
\hline & & $B$ & Std. Error & & \\
\hline \multirow[t]{3}{*}{1} & (Constant) & -146069.153 & 99726.816 & & 149 \\
\hline & PAD & 1.265 & .036 & .622 & .000 \\
\hline & DAU & 1.539 & .044 & .625 & .000 \\
\hline
\end{tabular}

Sumber : Data Diolah, 2016

Berdasarkan pada tabel 4.10, diperoleh hasil nilai koefisien DAU sebesar 1.539 dan nilai koefisien PAD sebesar 1,265 dan keduanya signifikan dengan nilai sig. 0,000 < 0,05 untuk DAU dan PAD. Dengan demikian Flypaper Effect menyatakan pengaruh DAU terhadap Belanja Daerah lebih besar daripada pengaruh PAD terhadap Belanja Daerah diterima. Hal ini berarti telah terjadi flypaper effect pada Belanja Daerah.

\section{Pembahasan}

Berdasarkan Hasil statistik deskriptif menunjukkan rentang nilai maksimum dan minimum PAD yang sangat jauh, keadaan ini mencerminkan ketimpangan kemampuan daerah yang cukup besar.

Hasil uji secara parsial menyatakan bahwa hasil analisis ditunjukkan tingkat signifikansi $0.000<0.05$, Sehingga dapat diartikan bahwa terdapat pengaruh yangsignifikan variabel Pendapatan Asli Daerah (PAD) terhadap Belanja Daerah di kabupaten/kota yaitu Provinsi Jawa Timur, Jawa Tengah dan Jawa Barat hal ini dapat diartikan bahwa pengeluaran pemerintah daerah akan disesuaikan dengan perubahan dalam penerimaan pemerintah daerah atau perubahan pendapatan terjadi sebelum perubahan pengeluaran. Hal ini sejalan dengan penelitian (Wulansari, 2015) yang menyatakan bahwa Pendapatan Asli Daerah (PAD) berpengaruh positif terhadap belanja daerah. 
Hasil uji secara parsial menyatakan bahwa hasil analisis ditunjukkan Tingkat signifikansi $0.000<0.05$, Sehingga dapat diartikan bahwa terdapat pengaruh yang signifikan variabel Dana Alokasi Umum (DAU) terhadap Belanja Daerah di kabupaten/kota yaitu Provinsi Jawa Timur, Jawa Tengah dan Jawa Barat.

Hasil uji secara simultan (uji F) menyatakan bahwa secara bersama-sama Pendapatan Asli Daerah (PAD) dan Dana Alokasi Umum (DAU) berpengaruh positif signifikan terhadap Belanja Daerah (BD) di Provinsi Jawa Timur, Jawa Tengah dan Jawa Barat. Dengan demikian Ho tidak diterima Ha diterima yang menyatakan bahwa PAD dan DAU secara simultan berpengaruh signifikan terhadap belanja daerah Kabupaten/Kota di Provinsi Jawa Timur, Jawa Tengah dan Jawa Barat.

Hasil nilai koefisien DAU sebesar 1,539 dan nilai koefisien PAD sebesar 1,265 dan keduanya signifikan dengan nilai sig. 0,000<0,05 untuk DAU dan PAD. Dengan demikian Flypaper Effect menyatakan pengaruh DAU terhadap Belanja Daerah lebih besar daripada pengaruh PAD terhadap Belanja Daerah diterima.

\section{Kesimpulan}

Berdasarkan hasil analisis dan pembahasan diatas maka peneliti dapat menarik kesimpulan bahwa Pendapatan Asli Daerah (PAD) berpengaruh terhadap Belanja Daerah Pemerintahan Kabupaten/Kota Provinsi Jawa Timur, Jawa Tengah dan Jawa Barat Tahun 2011-2013; Dana Alokasi Umum (DAU) berpengaruh terhadap Belanja Daerah Pemerintahan Kabupaten/Kota Provinsi Jawa Timur, Jawa Tengah dan Jawa Barat Tahun 2011-2013; dan Terjadi Flypaper Effect Dana Alokasi Umum dan Pendapatan Asli Daerah terhadap Belanja Daerah Pemerintahan Kabupaten/Kota Provinsi Jawa Timur, Jawa Tengah dan Jawa Barat Tahun 2011-2013.

\section{Daftar Pustaka}

Amalia, Wia Rizqi, dkk. . 2015. Flypaper Pada Pendapatan Asli Daerah (PAD), DanaAlokasi Umum (DAU) dan Dana Alokasi Khusus (DAK) Terhadap Belanja Daerah (BD) Pada Pemerintahan Kabupaten/Kota di Provinsi Kalimantan Selatan (2009-2013).

Elmi, Bachrul. 2002. Keuangan Pemerintah Daerah Otonom di Indonesia. Jakarta: UI Press.

Ghozali, Imam. 2009. Aplikasi Analisis Multivariate dengan Program SPSS. Semarang: Badan Penerbit Universitas Diponegoro. 
Halim, Abdul. 2008. Akuntansi Keuangan Daerah. Jakarta: Salemba Empat.

Halim, Abdul dan Abdullah S. 2004. Pengaruh Dana Alokasi Umum (DAU) \& PendapatanAsli Daerah (PAD) Terhadap Belanja Pemerintahan Daerah (Studi Kasus Kabupaten/Kota di Jawa dan Bali). Jurnal Ekonomi STEI Vol. 13 (2):19-109.

Hidayani, Suci Chusnul. 2014. Apakah Terjadi Flypaper Effect Pada Belanja DaerahProvinsi Jawa Timur ? JURNAL ILMU \& RISET AKUNTANSI Vo. 3 No. 1.

http://bpnjatim.wordpress.com

http://usepmulyana.files.wordpress.com/2008/11/rancangan-penelitian.doc

Iskandar. 2008. Metodologi Penelitian Pendidikan dan Sosial (Kuantitatif dan Kualitatif). Jakarta: Gaung Persada Press.

Iskandar, Budi. 2012. Flypaper Effect Pada Unconditional Grants. Jurnal Ekonomi Pembangunan Vol. 13 (1):113-131.

Jolianis. Desember 2014. Pengaruh Dana Alokasi Umum (DAU) dan pendapatan AsliDaerah (PAD) Terhadap Belanja Daerah Pada Kabupaten/Kota di Provinsi Sumatera Barat. Pelangi Vo. 7 No.1:Hal.47-60.

Maimunah, Mutiara. 2006. Flypaper Effect Pada Dana Alokasi Umum (DAU) danPendapatan Asli Daerah (PAD) Terhadap Belanja Daerah Pada Kabupaten/Kota di Pulau Sumatera. Simposium Nasional Akuntansi 9 Padang.

Mardiasmo, MBA, Ak. 2007. Otonomi \& Manajemen Keuangan Daerah. Yogjakarta: ANDI.

Nordiawan, Deddi. 2008. Akuntansi Pemerintahan. Jakarta: Salemba Empat.

Peraturan Menteri Dalam Negeri No. 13 Tahun 2005 Tentang Pedoman Pengolahan Keuangan Daerah

Peraturan Pemerintah Nomor 58 Tahun 2005 Tentang Pengelolaan Keuangan Daerah

Prahesti, Alifani Indah. 2014. Flypaper Effect Pada Dana Alokasi Umum dan PendapatanAsli Daerah Terhadap Belanja Daerah Bondowoso. JURNAL ILMU \& RISETAKUNTANSI VOL. 3 No. 5.

Purbarini, Endah dan Gregorius N. Masdjojo. 2015. Flypaper Effect pada Belanja operasidan Belanja Modal dari Pemerintahan Kota di Indonesia. Jurnal EkonomiPembangunan:Hal. 75-84.

Purnomo, Budi. 2009. Obligasi Daerah. Bandung: Alfabeta.

Santoso, Singgih. 2005. Menguasai Statistik di Era Informasi dengan SPSS 12. Jakarta: PT. Alex Media Komputindo.

Sasana, Hadi. 2010. Flypaper Effect Pada Dana Alokasi Umum, Dana Bagi Hasil \&Pendapatan Asli Daerah Terhadap Belanja Daerah Pada Provinsi Indonesia. Jurnal Ekonomi Regional Vol. 5 (2).

Shinta, Dian Ayu. 2009. Perilaku Asimetris Pemerintahan Daerah Terhadap Transfer dariPemerintahan Pada Kabupaten/Kota di Jawa Tengah Skripsi Sarjana EkonomiAkuntansi Purwokerto.

Sidik, Machfud, dkk. 2002. Dana Alokasi Umum- Konsep, Hambatan dan Prospek di EraOtonomi Daerah. Jakarta: Buku Kompas.

Soleh, Chabib dan Heru Rochmansjah. 2010. Pengelolaan Keuangan dan Aset Daerah. Fokusmedia. 
Sugiyono. 2012. METODE PENELITIAN KUANTITATIF, KUALITATIF DAN $R \& D$. Cetakan Ke-17. Bandung: Alfabeta.

Sugiyono. 2013. Metode Penelitian Pendidikan Pendekatan Kuantitatif, Kualitatif dan $R \& D$. Bandung: Alfabeta.

Sunarto. 2005. MSDM Strategik. Yogjakarta: Amus.

Ulum, Ihyaul. 2008. Akuntansi Sektor Publik Edisi Revisi. Malang: UMM PRESS.

Undang-Undang Nomor 32 Tahun 2004 Tentang Pemerintahan Daerah

Undang-Undang Nomor 33 Tahun 2004 Tentang Perimbangan Keuangan Antara Pemerintahan Pusat dan Pemerintahan Daerah

Wulansari, Dessy Tri. 2015. Pengaruh Pendapatan Asli Daerah (PAD) dan DanaPerimbangan Terhadap Belanja Daerah Serta Analisis Flypaper Effect.

www.djpkpd.go.id.

www.jabarprov.go.id

www.kemendagri.go.id 
